\title{
EFL TEACHERS' SELF-EFFICACY BELIEFS AND THEIR (NON)-COMMUNICATIVE INSTRUCTIONAL PRACTICES
}

\author{
Marzieh Sadat Mirmojarabian ${ }^{\mathrm{a}}$, Ehsan Rezvani ${ }^{\mathrm{b}}$ \\ (asoheila.mojarab@gmail.com, be.rezvani@khuisf.ac.ir) \\ ${ }^{a, b}$ English Department, Isfahan (Khorasgan) Branch, \\ Islamic Azad University, Isfahan, Iran
}

\begin{abstract}
This study investigated Iranian EFL teachers' self-efficacy beliefs (TSEBs) about instructional strategies, student engagement and classroom management strategies they adopt for teaching. It also examined the relationship between TSEBs concerning the three sub-efficacies and teachers' use of (non) communicative instructional practices. The participants of the study were $48 \mathrm{EFL}$ teachers in Iranian language institutes. A survey questionnaire, semi-structured interviews, and classroom observations were administered to collect the data needed. The results demonstrated that teachers regarded themselves as highefficacious, and there was a moderate positive relationship between TSEBs in terms of the three sub-efficacies and communicative instructional practices. TSEBs towards instructional strategies had the highest contribution to explaining communicative practice, which was also confirmed by the interview results. The data from observations indicated that TSEBs were not realized regarding instructional strategies, but student engagement and classroom management strategies were reflected in teachers' instructions.
\end{abstract}

Keywords: classroom management, communicative practices, instructional strategies, student engagement, teachers' self-efficacy beliefs

DOI: http://dx.doi.org/10.15639/teflinjournal.v32i2/267-294

Teachers' self-efficacy beliefs (TSEBs), defined as teachers' perceptions in their abilities to effectively manage the tasks and challenges to help students learn (Bandura, 1986; Hoy et al., 2009), have the potential to influence teacher behavior. Previous research highlighted the importance of TSEBs in teaching and learning (Bandura, 1997; Morris et al., 2017; Tschannen-Moran \& Hoy, 2001). First of all, they are linked to behavior patterns that teachers show in the classroom. Teachers with a high sense of efficacy make a commitment to difficult 
situations (Coladarci, 1992; Tschannen-Moran et al., 1998). Moreover, teachers who feel capable of teaching welcome more innovative teaching practices (Werthein \& Leyser, 2002). Research has also found that TSEBs are related to the passion for teaching, specifically in the early years of a teacher's career (Moe, 2016).

There has been an interest in TSEBs in different domains; however, research into language teachers' self-efficacy has received particular interest (Wyatt, 2018). More recently, TSEBs have been referred to as teachers' attitudes in their abilities to support learning with various tasks, in different contexts through cognitive, metacognitive, affective, and social ways (Wyatt, 2018). The emphasis on context draws one's attention to the impact of contextual factors on language TSEBs. As a result, factors such as differences between an urban and a rural school (Siwatu, 2011), the influence of national culture (Phan \& Locke, 2016), the nature of the course material available (Ganjabi, et al., 2013), the teachers' multiple intelligences (Khosravi \& Saidi, 2014) have been explored. A striking finding in this line of research showed emotional intelligence, the capacity to identify and comprehend one's emotions, correlated negatively with TSEBs in the study done by Moafian and Ghanizadeh (2009). It suggests that if teachers are more emotionally self-aware, they may be less efficacious.

Additionally, the possible impact which TSEBs may have on student outcomes has been the focus of some research (Wyatt, 2018). A considerable justification must be the intuition that efficacious language teachers are more likely to find ways to have a beneficial impact on student learning. For example, a study done by Swanson (2014) found positive relationships between the variables. TSEBs were also found to lead to students' motivation (Lazarides, et al., 2018) as well as their satisfaction (Rashidi \& Moghadam, 2014).

TSEBs can be explored through various dimensions; however, the most contributing ones to effective learning are teachers' capability to implement instructional strategies, student engagement strategies and classroom management strategies. The overriding importance of the three subscales was reported in assessing self-efficacy in research by Tschannen-Moran and Hoy (2001). In another study by Eslami and Fatahi (2008), the EFL teachers reported rather high levels of efficacy in adopting the three subscales of instructional strategies, classroom management strategies and student engagement strategies. The result demonstrated that the more self-efficacious the teachers were, the more inclined they were to use communicative-orientation instructional practices. Earlier, Chacón (2005) had applied the same procedures. Despite the 
relationship between TSEBs and both communicative and non-communicative teaching approaches, there was a much bigger tendency for teachers to employ non-communicative instructional practices based on interview findings.

The finding from a recent study by Choi and Lee (2018) indicated that TSEBs were significantly related to the use of teaching student-centered communicative practices. Among the three subtypes of self-efficacy, classroom management efficacy positively contributed to using communicative instructional practices and was negatively associated with non-communicative teaching practices. Interview findings about (non)communicative instructional practices used by teachers also revealed that higher classroom management skills have contributed to more communicative teaching.

Contrary to the abovementioned, the research by Ortaçtepe and Akyel (2015) was one of the studies that indicated no significant relationship between the teachers' TSEBs and their self-reported use of communicative instructional practices. Nonetheless, efficacy beliefs and their confidence in employing communication-oriented instructional practices increased after an in-service developmental program to help teachers in communicative teaching. A recent research study that benefited from classroom observations is the one by Poulou et al. (2019), which examined TSEBs and instructional and behavior management teaching practices using the classroom strategies assessment system (CSAS), a multidimensional validated observation system. Teachers completed the teacher sense of efficacy scale and were observed using the CSAS by independent observers. Significant differences between teachers' selfreported self-efficacy and observers' ratings were found within domains of instructional and classroom behavioral management strategies.

Although noticeable research on self-efficacy has been conducted in Middle Eastern countries, according to Hoang (2018), only two noteworthy research studies explored how TSEBs were associated with instructional practices in an Iranian context. The two studies were conducted by Eslami and Fatahi (2008) and Moradkhani et al. (2017). The latter, however, probed Iranian EFL teachers' reflective practices and self-efficacy. Likewise, Klassen et al. (2011) claim most of the studies on teachers' self- efficacy and instructional practices have been based on self-reports of both constructs. Accordingly, there is a need to expand research to examine teachers' self-reported efficacy with other methods, such as direct observations of teaching practices (Holzberger et al., 2013). Due to the scarcity of research on the TSEBs and classroom instructional practices in Iran, the present study aimed at examining not only how such beliefs are related to 
(non)communicative instructional practices but also the extent to which TSEBs were reflected in practice. Accordingly, the following research questions were posed:

1. What are Iranian EFL TSEBs concerning instructional strategies, student engagement and classroom management strategies?

2. Is there a relationship between Iranian EFL TSEBs and their use of communicative versus non-communicative instructional practices?

3. To what extent are EFL TSEBs realized in teachers' instructional practices?

\section{METHOD}

The present study is a descriptive correlational study utilizing questionnaires, interviews, and observations as the techniques to collect the data.

\section{Participants}

The participants of the study were English teachers working at different language centers in Iran. A notice was put up in a number of language institutes and the teachers who were willing and available to participate in the survey took part in the study. Initially, the survey was administered to 48 English teachers about two-thirds of whom were females (females $=34$, males $=14$ ). They ranged from less experienced teachers to experienced ones aged between 20 to over 40 with an educational degree from Bachelors to Ph.D. graduates. Later, among 30 participants who agreed to participate in the interviews and observations, 10 teachers of both genders were selected. An attempt was made to make the sample as representative as possible to the whole population.

\section{Instruments}

\section{Questionnaire}

A questionnaire with three subsections (Choi \& Lee, 2018) was employed in the present study. The first section collected the teachers' demographic information. The second section, with 21 items on a seven-point Likert scale, asked the teachers to rate their self-efficacy levels concerning instructional strategies, student engagement, and classroom management strategies. The third section, with seven items on a five-point rating scale, measured how frequently teachers use (non)communicative teaching practices based on previous research 
(Richards, 2008). Confirmatory factor analyses were conducted in scale development of the questionnaires, on the sub-scales to offer the construct validity. The reliability of each subscale is reasonable to high internal consistency (Choi \& Lee, 2018).

\section{Interviews}

To elicit qualitative information about the relationship between self-efficacy and instructional practices, a semi-structured one-to-one interview was conducted using three predetermined questions adopted from research by Choi and Lee (2018). The interview asked about teachers' current instructional techniques and their confidence in (non)communicative instructional practices. It also sought the teachers' reasons for the confidence they claimed. Three participants were interviewed in person in the mentioned language institutes. Each interview lasted for about 30 minutes and was audio-recorded. The other seven interviews were conducted by phone on a scheduled time and recorded. The researcher did the interviews and transcribed them to be used in subsequent phases of the research. Although the interviews were done in English, the necessary clarification was provided in Farsi. In other words, when the teachers did not exactly understand the interview questions, the interviewer switched to their first language (i.e. Farsi) to further clarify the points and elicit more relevant responses.

\section{Observation}

Classroom Strategy Assessment System (CSAS), an evidence-based teacher classroom observation assessment (Reddy et al., 2013), was used in the present study. The CSAS observation form measures how the teachers use instructional and behavioral management strategies in their classrooms. It has three parts: strategy counts, strategy rating scales, and classroom checklist. The first part consists of eight instructional and behavioral strategies that are tallied and tabulated during the observation. The second part has two sections, that is, instructional strategies (IS) and behavioral management strategies (BMS). The IS scale includes 30 items and five subscales: adaptive instruction (four items), student-directed instruction (five items), direct instruction (eight items), promotes student thinking (six items), and academic performance feedback (seven items). Similarly, the BMS scale includes 30 items, and four subscales: directives (eight items), proactive methods (eight items), praise (six items), and 
corrective feedback (eight items). The third part, the classroom checklist, was not utilized in this study because based on the research questions, it was not necessary to use the checklist.

Based on Reddy et al. (2013), CSAS form indicated evidence for good reliability, content, construct, and predictive validity. High levels of internal consistency have been documented across the CSAS multiple components (Cronbach's alphas $>0.90$ ) with fair to good test-retest reliability across a two to three-week span $(r>0.70)$. The assessment evidences freedom of item bias for teacher's age, educational degree, and years of teaching experience (Reddy et al., 2013).

\section{Procedures}

First, electronic versions of the questionnaire were developed using Google Forms. Next, the questionnaire was shared on social networking applications (Telegram and WhatsApp) of teachers in the five English language institutes in Isfahan, Iran. The criteria for choosing these institutes were their reputation and long history in English language teaching. Moreover, these institutes provided us with a wide range of EFL teachers with diverse characteristics in terms of age, gender, and teaching experience who could contribute to our study. To obtain qualitative data to develop an in-depth understanding of the issue, teachers were asked to provide their consent through an item in questionnaires. Thirty teachers volunteered to participate in individual interviews. Ten participants scoring the highest and lowest in self-efficacy scales were selected out of the 30 teachers who volunteered to achieve maximum variation sampling (Devers \& Frankel, 2000). They were assigned a range from the most efficacious teacher (identified as interviewee A) to the least-efficacious one (identified as interviewee J). Accordingly, they were contacted via email to arrange a time that was mutually convenient for the interview. Three predetermined questions were asked to gain more information on their confidence in utilizing communicative versus noncommunicative practices.

Finally, the participants who agreed to be observed were among the same teachers who voluntarily answered the questionnaire survey and participated in the interview. The number was not fixed in advance; however, the number reached 10 observations for different individual teachers making the obtained data more reliable. The number of observations (10) was guided by data saturation when no new information was observed in the data (Fusch \& Ness, 2015). 
Although most face-to-face English classes were substituted with online classes due to the Corona virus pandemic, the resistance and dissatisfaction of some students made the institutes hold classes after the lockdown. The sessions were reduced from 90 minutes to 60 minutes, and the number of students was limited (ranging from 5 to 8 ). It brought the opportunity for the researcher to do the observations.

The CSAS observation form (Reddy et al. 2013) was requested via email from the main author. The teachers were observed using this form in order to determine the extent to which instructional strategies and classroom management strategies were implemented in instructional practices. Before classroom observations, the observer talked with teachers to review their intended learning objectives and related lesson plans. CSAS observations ranged between 50 to 60 minutes and during the beginning of the classroom observation, any information relevant to the classroom context was recorded by the observer.

While the teachers were teaching the classroom, the observer tallied the number of times the teacher displayed instructional and behavioral strategies related to the first part of the observation form. The strategies were marked either used by the teacher for an individual student or a group of students. The data obtained from this part was not used directly to answer the third research question; however, the information was gathered and utilized as a reminder while answering the second part of the observation form.

The second part was completed immediately after each classroom observation. To this end, the observer completed all 60 items related to IS and BMS based on what had been observed in classrooms regarding the frequency of strategies teachers successfully employed and the expected strategies. The observer first rated how often the teacher used each strategy (observed frequency), and then how often the teacher should have used the same strategy (expected frequency). Next, the discrepancy score was calculated to take the absolute value of the difference. This procedure was repeated for all 10 participants.

Several ethical considerations such as informed consent, privacy, anonymity, and confidentiality of participant data were observed. The current study used pseudonyms to maintain anonymity and confidentiality. Information linking the teacher to their pseudonym was stored separately and only available to the researcher. Similarly, before observations, all participating teachers were assured of the confidentiality of the information collected by the observer. Institutions directors were informed about the study and permission was obtained 
by the researcher to observe classes for the present investigation. Although the observations were done in different branches of Jahad Daneshgahi, Isfahan branch where the researcher was working as an English teacher, and some of the teachers knew the researcher, the teachers' participation in the study was voluntary and the researcher was not in a position of power or influence over any of the teachers. The researcher was also in charge of the distribution of questionnaires, the interview scheduling, and observation sessions.

To analyze the data, first, descriptive statistics were computed to summarize teachers' responses to the self-efficacy questionnaire. Then, a Pearson correlational analysis was performed to investigate the relationship between selfefficacy and communicative versus non-communicative instructional practices. Next, two simultaneous multiple regressions were done to examine the contributions of the three subscales to (non)communicative instructional practices. After that, the interview responses were analyzed based on each participant's questionnaire answers that involved analytical techniques such as counting, making contrasts, and comparisons.

Finally, the data gathered by observation forms were used, and the mean scores of all 10 participants on each subscale of IS and BMS as well as total scores were obtained. Then, the mean scores for observed and expected frequencies were compared via chi-square to determine any significant difference. The results of the analysis procedures are presented in the following.

\section{FINDINGS AND DISCUSSION}

\section{Findings}

\section{EFL Teachers'Self-efficacy Beliefs}

The three subscales were analyzed separately and presented in Tables 1 to 3. Table 1 deals with the instructional strategies' subscale of the questionnaire. Each choice in this Likert-scale questionnaire was assigned a value ranging from 1 to 6 ; thus, the mean score of each questionnaire item $(21 / 6=3.50)$ was compared with the average score of the choices. It would mean that if the mean score of the given questionnaire item was less than 3.50, the respondent teachers tended to have a rather low perceived self-efficacy with that item/statement. In contrast, a mean score of more than 3.50 indicated the respondents' inclination 
to perceive themselves self-efficacious concerning the trait being described in the statement.

Table 1. EFL Teachers' Self-efficacy Regarding Instructional Strategies

\begin{tabular}{|c|c|c|c|c|c|c|c|}
\hline Statements & 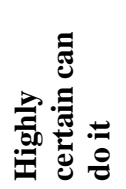 & 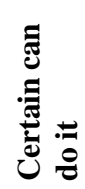 & 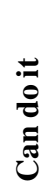 & 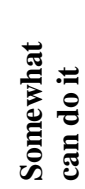 & 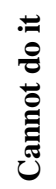 & 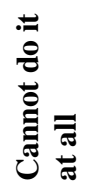 & $\sum_{\bar{\Sigma}}^{\bar{E}}$ \\
\hline $\begin{array}{l}\text { 1. Provide alternative } \\
\text { explanations. }\end{array}$ & 33 & 12 & 3 & 0 & 0 & 0 & 5.62 \\
\hline $\begin{array}{l}\text { 2. Use a variety of assessment } \\
\text { strategies. }\end{array}$ & 12 & 22 & 11 & 3 & 0 & 0 & 4.89 \\
\hline $\begin{array}{l}\text { 3. Adjust teaching activities as } \\
\text { needed. }\end{array}$ & 21 & 21 & 5 & 1 & 0 & 0 & 5.29 \\
\hline $\begin{array}{l}\text { 4. Accurately deliver content } \\
\text { knowledge. }\end{array}$ & 16 & 21 & 10 & 1 & 0 & 0 & 5.08 \\
\hline 5. Provide specific feedbacks. & 18 & 21 & 9 & 0 & 0 & 0 & 5.18 \\
\hline $\begin{array}{l}\text { 6. Solicit a variety of good } \\
\text { questions. }\end{array}$ & 17 & 21 & 9 & 1 & 0 & 0 & 5.12 \\
\hline $\begin{array}{l}\text { 7. Use methods for students' } \\
\text { differences. }\end{array}$ & 7 & 23 & 14 & 4 & 0 & 0 & 4.68 \\
\hline $\begin{array}{l}8 \text { Communicate the objectives of } \\
\text { the lesson. }\end{array}$ & 10 & 22 & 16 & 0 & 0 & 0 & 4.87 \\
\hline Total & 134 & 163 & 77 & 10 & 0 & O & 5.09 \\
\hline
\end{tabular}

The mean scores of all the eight questionnaire items relevant to perceptions of EFL teachers regarding instructional strategies were found to be larger than 3.50, which means that the surveyed EFL teachers found themselves selfefficacious with regard to instructional strategies. The items with the highest mean scores were items \# $1(M=5.62), 3(M=5.29)$, and $5(M=5.18)$, in which they asserted that they could (a) provide students with an alternative explanation when they are confused, (b) adjust learning/teaching activities as needed, and (c) provide students with specific feedback about their learning, respectively. The overall mean score for this section of the questionnaire equaled 5.09, which is well above the average value of the choices. In Table 2, EFL teachers' perceptions of student engagement are delineated. 
276 TEFLIN Journal, Volume 32, Number 2, July 2021

Table 2. EFL Teachers' Self-efficacy Regarding Student Engagement

\begin{tabular}{|c|c|c|c|c|c|c|c|}
\hline Statements & 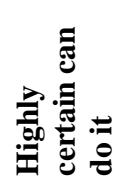 & : & لَّ & 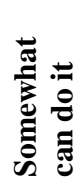 & 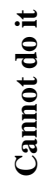 & 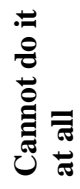 & 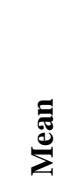 \\
\hline $\begin{array}{l}\text { 1. Get students believe they can do } \\
\text { well. }\end{array}$ & 21 & 22 & 5 & 0 & 0 & 0 & 5.33 \\
\hline $\begin{array}{l}\text { 2. Help students value learning } \\
\text { English. }\end{array}$ & 23 & 17 & 7 & 1 & 0 & 0 & 5.29 \\
\hline $\begin{array}{l}\text { 3. Use teaching methods to } \\
\text { motivate students. }\end{array}$ & 22 & 15 & 11 & 0 & 0 & 0 & 5.22 \\
\hline $\begin{array}{l}\text { 4. Clarify student } \\
\text { misunderstandings. }\end{array}$ & 28 & 14 & 6 & 0 & 0 & 0 & 5.45 \\
\hline $\begin{array}{l}\text { 5. Maintain high levels of student } \\
\text { engagement. }\end{array}$ & 18 & 25 & 4 & 1 & 0 & 0 & 5.25 \\
\hline $\begin{array}{l}\text { 6. Provide a positive influence on } \\
\text { students. }\end{array}$ & 16 & 20 & 10 & 2 & 0 & 0 & 5.04 \\
\hline $\begin{array}{l}\text { 7. Motivate students to their fullest } \\
\text { potential. }\end{array}$ & 21 & 19 & 7 & 1 & 0 & 0 & 5.25 \\
\hline Total & 149 & 132 & 50 & 5 & $\mathbf{0}$ & $\mathbf{0}$ & 5.26 \\
\hline
\end{tabular}

The mean scores for all the items were larger than the average value of the choices, and the highest mean scores belonged to items \# $4(M=5.45), 1(M=$ $5.33)$, and $2(M=5.29)$, through which the teachers remarked that they could respectively (a) clarify student misunderstandings or difficulties in learning, (b) get students to believe they could do well in English, and (c) help students value learning English. The overall mean score for the student engagement subsection of the questionnaire amounted to 5.26, which indicated that the teachers regarded themselves as self-efficacious with regard to student engagement. Table 3 presents the teachers' perceptions of self-efficacy with respect to classroom management. 
Table 3. EFL Teachers' Self-efficacy Regarding Classroom Management

\begin{tabular}{|c|c|c|c|c|c|c|c|}
\hline Statements & 苞 & 。 & ن & 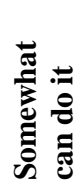 & 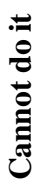 & 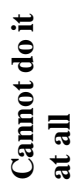 & 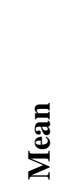 \\
\hline 1. Control disruptive behavior. & 11 & 24 & 7 & 6 & 0 & 0 & 4.83 \\
\hline $\begin{array}{l}\text { 2. Maintain a positive classroom } \\
\text { climate of courtesy. }\end{array}$ & 25 & 18 & 5 & 0 & 0 & 0 & 5.41 \\
\hline $\begin{array}{l}\text { 3. Create an atmosphere to use } \\
\text { English freely in class. }\end{array}$ & 21 & 19 & 8 & 0 & 0 & 0 & 5.27 \\
\hline $\begin{array}{l}\text { 4. Effectively use allocated time } \\
\text { for various activities. }\end{array}$ & 16 & 20 & 9 & 2 & 1 & 0 & 5.00 \\
\hline $\begin{array}{l}\text { 5. Establish a classroom } \\
\text { management system. }\end{array}$ & 15 & 22 & 7 & 4 & 0 & 0 & 5.00 \\
\hline $\begin{array}{l}\text { 6. Have students work. } \\
\text { cooperatively. }\end{array}$ & 24 & 17 & 7 & 0 & 0 & 0 & 5.35 \\
\hline Total & 112 & 120 & 43 & 12 & 1 & $\mathbf{0}$ & 5.14 \\
\hline
\end{tabular}

Table 4 divulges the fact that all the three subscales of teachers' self-efficacy were above average, and student engagement had the highest overall mean score, followed by classroom management and instructional strategies. Moreover, all the three subscales of self-efficacy had mean scores that were significantly above average since the $p$ values corresponding to them were lower than the .05 significance level $(p<.05)$.

Table 4. One-Sample t Test for Teachers' Self-efficacy

\begin{tabular}{|l|c|c|c|c|c|c|}
\hline & \multicolumn{5}{|c|}{ Test Value =3 } \\
\cline { 2 - 7 } & $\begin{array}{c}\text { Overall } \\
\text { Mean }\end{array}$ & $\boldsymbol{t}$ & $\boldsymbol{d f}$ & $\begin{array}{c}\text { Sig. } \\
\text { (2-tailed) }\end{array}$ & \multicolumn{2}{|c|}{$\begin{array}{c}\text { 95\% Confidence } \\
\text { Interval of the } \\
\text { Difference }\end{array}$} \\
\cline { 5 - 7 } & & & Lower & Upper \\
\hline $\begin{array}{l}\text { Instructional } \\
\text { Strategies }\end{array}$ & 5.09 & 15.54 & 7 & .00 & 1.34 & 1.83 \\
\hline
\end{tabular}


278 TEFLIN Journal, Volume 32, Number 2, July 2021

\begin{tabular}{|l|c|c|c|c|c|c|}
\hline & \multicolumn{3}{|c|}{ Test Value = 3 } \\
\cline { 2 - 7 } & $\begin{array}{c}\text { Overall } \\
\text { Mean }\end{array}$ & $\boldsymbol{t}$ & $\boldsymbol{d f}$ & $\begin{array}{c}\text { Sig. } \\
\text { (2-tailed) }\end{array}$ & \multicolumn{2}{|c|}{$\begin{array}{c}\text { 95\% Confidence } \\
\text { Interval of the } \\
\text { Difference }\end{array}$} \\
\cline { 3 - 7 } & & & Lower & Upper \\
\hline $\begin{array}{l}\text { Student } \\
\text { Engagement }\end{array}$ & 5.26 & 37.61 & 6 & .00 & 1.64 & 1.87 \\
\hline $\begin{array}{l}\text { Classroom } \\
\text { Management }\end{array}$ & 5.14 & 17.35 & 5 & .00 & 1.39 & 1.88 \\
\hline
\end{tabular}

\section{Association Between Self-efficacy and (Non) Communicative Instructional Practices}

The results of Pearson correlation are presented in Table 5.

Table 5. Correlation Between Self-efficacy and Communicative Practices

\begin{tabular}{|l|l|l|}
\hline \multicolumn{2}{|c|}{} & $\begin{array}{l}\text { Communicative } \\
\text { Practices }\end{array}$ \\
\hline \multirow{4}{*}{ Self-efficacy } & $\begin{array}{l}\text { Pearson } \\
\text { Correlation }\end{array}$ & $.48^{*}$ \\
\cline { 2 - 3 } & Sig. (2-tailed) & .00 \\
\cline { 2 - 3 } & $N$ & 48 \\
\hline
\end{tabular}

As shown in Table 5, the correlation between self-efficacy and communicative practices was a moderately positive one $(r=.48)$ because based on Farhady et al. (1994), a relationship is weak if it is lower than \pm .30 , moderate if it falls between \pm .30 and \pm .50 , and strong if it is over \pm .50 . This moderate positive relationship between self-efficacy and communicative practices of EFL teachers reached statistical significance because of the $p$-value in front of the Sig. (2-tailed) was smaller than the significance level $(p<.05)$.

A standard multiple regression analysis was also conducted to investigate the roles of instructional strategies, student engagement, and classroom management in communicative classroom practices of EFL teachers. Multiple regression was used since there were three independent variables and one dependent variable to be investigated in this part of the study. Table 6 presents the results of the model run by multiple regression. 
Table 6. Model Summary for Multiple Regression (Communicative Practices)

\begin{tabular}{|c|c|c|c|c|}
\hline Model & $\boldsymbol{R}$ & $\boldsymbol{R}$ Square & Adjusted $\boldsymbol{R}$ Square & Std. Error of the Estimate \\
\hline 1 & .48 & .23 & .18 & 1.52 \\
\hline
\end{tabular}

In Table 6, the value given under the $R$ Square column shows how much of the variance in communicative practices could be accounted for by instructional strategies, student engagement, and classroom management. The value here is .23 , which means that instructional strategies, student engagement, and classroom management explained 23 percent of the variance in the EFL teachers' classroom practices. To examine the statistical significance of this result, Table 7 had to be checked.

Table 7. Statistical Significance of the Multiple Regression Results for Communicative Practices

\begin{tabular}{|l|c|c|c|c|c|}
\hline & Sum of Squares & $\boldsymbol{d f}$ & Mean Square & $\boldsymbol{F}$ & Sig. \\
\hline Regression & 32.01 & 3 & 10.67 & 4.56 & .00 \\
\hline Residual & 102.96 & 44 & 2.34 & & \\
\hline Total & 134.97 & 47 & & & \\
\hline
\end{tabular}

In Table 7, the $p$ value under the Sig. column equaled .00, which was lower than the significance level $(p<.05)$, indicating that the model reached statistical significance. In other words, instructional strategies, student engagement, and classroom management could significantly predict communicative classroom practices of EFL teachers. Now Table 8 should be checked to see which of the independent variables could play a more significant part in the prediction of classroom comunicative practices.

To compare the predictive power of instructional strategies, student engagement, and classroom management, the values under the Beta column under standardized coefficients should be checked. Looking down this column, one could notice that the largest value was the one for instructional strategies (.25), indicating that instructional strategies had the strongest contribution (among the three independent variables) to explaining communicative practices. the Beta value for classroom management (.19) was the second-highest Beta score under this column, indicating that classroom management was the secondbest predictor of the teachers' communicative practices. Lastly, there was student engagement with a Beta value of .09. None of these three independent variables 
per se could significantly predict the EFL teachers' communicative practices because of the $p$ values for these variables under the Sig. column were all higher than the significance level $(p>.05)$.

Table 8. Predictive Power of Instructional Strategies, Student Engagement, and Classroom Management for Communicative Practices

\begin{tabular}{|c|c|c|c|c|c|c|c|c|c|c|}
\hline \multirow{2}{*}{$\frac{\bar{d}}{\delta}$} & \multicolumn{2}{|c|}{ 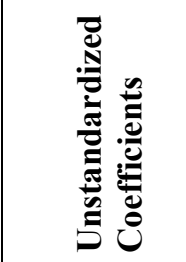 } & \multirow{2}{*}{ 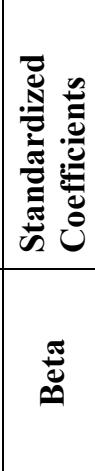 } & \multirow[t]{2}{*}{ N } & \multirow[t]{2}{*}{$\stackrel{\Delta \overrightarrow{0}}{\vec{D}}$} & \multicolumn{3}{|c|}{ 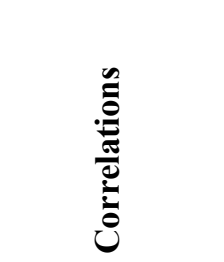 } & \multicolumn{2}{|c|}{ 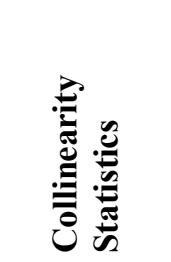 } \\
\hline & $\infty$ & 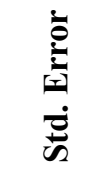 & & & & 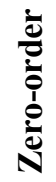 & لَّ & $\stackrel{\bar{E}}{\bar{E}}$ & 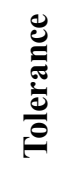 & 先 \\
\hline (Constant) & 8.23 & 2.58 & & 3.19 & .00 & & & & & \\
\hline IS & .10 & .08 & .25 & 1.31 & .19 & .45 & .19 & .17 & .45 & 2.20 \\
\hline SE & .04 & .08 & .09 & .54 & .58 & .38 & .08 & .07 & .53 & 1.87 \\
\hline $\mathrm{CM}$ & .09 & .09 & .19 & 1.07 & .28 & .42 & .16 & .14 & .51 & 1.95 \\
\hline
\end{tabular}

Note . IS= Instructional strategies, $\mathrm{SE}=$ Student engagement, $\mathrm{CM}=$ Classroom management

The results of the Pearson correlation for the association between selfefficacy on the one hand, and the EFL teachers' use of non-communicative classroom practices on the other are displayed in Table 9.

Table 9. Correlation Between Self-efficacy and Non-communicative Practices

\begin{tabular}{|l|l|l|}
\hline \multicolumn{2}{|c|}{} & Communicative Practices \\
\hline \multirow{3}{*}{ Self-efficacy } & Pearson Correlation & -.20 \\
\cline { 2 - 3 } & Sig. (2-tailed) & .16 \\
\cline { 2 - 3 } & $N$ & 48 \\
\hline
\end{tabular}

Table 9 revealed that the correlation between self-efficacy and noncommunicative practices was a weak negative one $(r=-.20)$ which failed to reach statistical significance because the $p$ value for under the Sig. column was 
higher than the significance level $(p>.05)$. To examine the predictive roles of instructional strategies, student engagement, and classroom management in noncommunicative classroom practices of EFL teachers, a standard multiple regression was conducted. Table 10 presents the results of the model run by multiple regression.

Table 10. Model Summary for Multiple Regression: Non-communicative Practices

\begin{tabular}{|c|c|c|c|c|}
\hline Model & $\boldsymbol{R}$ & $\boldsymbol{R}$ Square & Adjusted $\boldsymbol{R}$ Square & Std. Error of the Estimate \\
\hline $\mathbf{2}$ & .30 & .09 & .03 & 2.03 \\
\hline
\end{tabular}

In Table 10, it could be found that only nine percent of the variance in noncommunicative practices could be accounted for by instructional strategies, student engagement, and classroom management. To examine the statistical significance of this result, Table 11 had to be consulted.

Table 11. Statistical Significance of the Multiple Regression Results for Non-Communicative Practices

\begin{tabular}{|l|l|l|l|l|l|}
\hline & Sum of Squares & $\boldsymbol{d f}$ & Mean Square & $\boldsymbol{F}$ & Sig. \\
\hline Regression & 18.53 & 3 & 6.18 & 1.49 & .22 \\
\hline Residual & 181.94 & 44 & 4.13 & & \\
\hline Total & 200.47 & 47 & & & \\
\hline
\end{tabular}

As it could be noticed in Table 11, the $p$-value under the Sig. column was greater than the significance level $(p>.05)$, which indicates that the model did not reach statistical significance. Differently put, instructional strategies, student engagement, and classroom management (as a composite variable) could not significantly predict non-communicative classroom practices of EFL teachers. Nonetheless, Table 12 should be examined to find out which of the independent variables could play a more significant role in the prediction of classroom noncommunicative practices. 
Table 12. Predictive Power of Instructional Strategies, Student Engagement, and Classroom Management for NonCommunicative Practices

\begin{tabular}{|c|c|c|c|c|c|c|c|c|c|c|}
\hline \multirow{2}{*}{$\frac{\bar{d}}{\stackrel{\delta}{g}}$} & \multicolumn{2}{|c|}{ 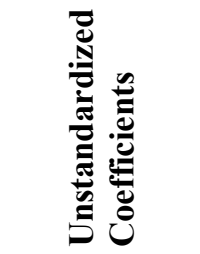 } & \multirow[t]{2}{*}{ 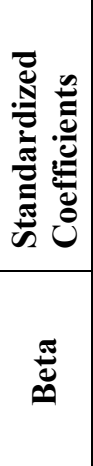 } & \multirow[t]{2}{*}{$\sim$} & \multirow{2}{*}{$\stackrel{\dot{00}}{\dot{D}}$} & \multicolumn{3}{|c|}{ نِّ } & \multicolumn{2}{|c|}{ 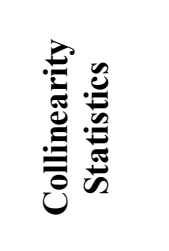 } \\
\hline & 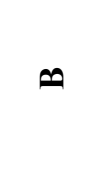 & 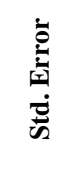 & & & & 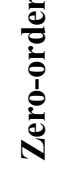 & & 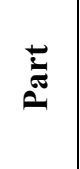 & 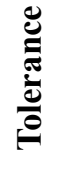 & $\frac{5}{7}$ \\
\hline (Constant) & 12.23 & 3.43 & & 3.56 & .00 & & & & & \\
\hline IS & .08 & .10 & .16 & .78 & .44 & -.10 & .11 & .11 & .45 & 2.20 \\
\hline SE & -.02 & .11 & -.04 & -.22 & .82 & -.15 & -.03 & -.03 & .53 & 1.87 \\
\hline $\mathrm{CM}$ & -.22 & .12 & -.36 & -1.82 & .07 & -.28 & -.26 & -.26 & .51 & 1.95 \\
\hline
\end{tabular}

Note. IS= Instructional strategies, $\mathrm{SE}=$ Student engagement, $\mathrm{CM}=$ Classroom management

In the Beta column under standardized coefficients, the highest value, irrespective of any negative marks, was the value for classroom management (.36), indicating that classroom management made the most contribution to explaining non-communicative practices. The Beta value for instructional strategies (.16) was the second-highest Beta score under this column, indicating that instructional strategies were the second-best predictor of the teachers' noncommunicative practices. Finally, there was student engagement with a Beta value of -.04 . None of these three independent variables could significantly predict the EFL teachers' non-communicative practices because the $p$ values for these variables under the Sig. column were all larger than the .05 level of significance.

\section{Interview Findings}

This section reports findings of the individual interviews with a purposeful sampling based on the summation of each individual's self-efficacy score for instructional, student engagement, and classroom management strategies. 
According to interview responses, the following findings were presented. In other words, interviews were conducted to ensure triangulation of data and enrich the findings obtained from the questionnaire survey and observations. The findings from the interview sessions clarified the teachers' opinions obtained from the questionnaire and helped us gain a better understanding of the teachers' practices observed during classroom observations. Regarding the first question in the interview, teachers depicted a variety of teaching methods and procedures as their current teaching methods included communicative and noncommunicative teaching. They believed that it is a necessity to take advantage of various methods, based on students' needs and wants. Interviewee H stated that due to different learning styles, she preferred the "eclectic method to be on the safe side."

Nonetheless, most teachers prioritized communication-focused instructional practices in their classrooms. The most common reason was students need to be exposed to English as much as possible to be able to communicate in real-life situations. The most self-efficacious teacher (interviewee A) pointed out that he is in favor of "conversation-based activities used in the Dogme approach which best suit students' interests." According to Thornbury (2000), Dogme English language teaching is a learner-focused approach. Dogme ELT is in line with CLT, and it is characterized by a focus on interactions between teachers and learners and the learners themselves.

Similarly, the least self-efficacious teacher among ten interviewees (interviewee J) responded that "it is more difficult to manage structured teachercentered teaching while simultaneously waking up students who keep nodding off." Surprisingly, she preferred interactive tasks in the communicative approach despite her low self-efficacy. Moreover, it became clear from other interviews that the communicative approach is the main component of high efficacious teachers. A couple of interviewees believed that using authentic materials would facilitate teaching and make students more motivated. As Interviewee $\mathrm{C}$ mentioned, "TED Talk is one of the best." TED (Technology, Entertainment, Design) Conference is an American media organization that posts talks online for free. Benefiting from such materials can compensate for learners' lack of knowledge and ideas while speaking English.

In the second interview question, teachers expressed their confidence regarding communicative/ non-communicative teaching practices. Although most teachers felt quite confident in adopting either approach, some mentioned the obstacles to implement the full version of CLT. Two teachers (interviewee F 
and $\mathrm{H}$ ) believed that teacher-fronted methods are less frequently used in the specific circumstances of their "more populated classes. It implies that the class atmosphere and students' preference do affect the flow of teaching. Considering the current EFL context in Iran, a remarkable number of students study English for academic purposes (Eslami \& Fatahi, 2008). Also, students' preference to gain sufficient language knowledge to beat University Entrance Exam justifies grammar-oriented instructional practices as well. Additionally, interviewee C, who reported a high level of self- efficacy, from a different point of view, stated that "The biased idea of not using $L 1$ should be avoided because based on recent research, students benefit undoubtedly". It implies that particularly in adult classes, use of L1 as a tool, is well justified.

\section{Realization of Teachers' Self-efficacy Beliefs in Instructional Practices}

In this section, the data obtained from the second part of the observation form were used. To this end, the observed frequencies and expected frequencies of the factors for instructional strategies and behavioral management strategies were rated. Then the mean scores of the whole participants for all scales in terms of instructional and behavioral strategies were compared via chi-square for goodness-of-fit (See Table 14). Any significant difference between the observed and expected frequencies would indicate no realization of the self-efficacy beliefs in instructional practices, while non-significant differences between the observed and expected frequencies would mean that the expected behaviors materialized in the instructional practices of the teachers.

Table 14. Chi-square Results for Instructional Strategies Section of the Observation Form

\begin{tabular}{|l|c|c|c|c|c|}
\hline $\begin{array}{l}\text { Instructional } \\
\text { strategies }\end{array}$ & $\begin{array}{c}\text { Observed } \\
\text { Frequency }\end{array}$ & $\begin{array}{c}\text { Expected } \\
\text { Frequency }\end{array}$ & $\begin{array}{c}\text { Discrepancy } \\
\text { Score }\end{array}$ & $\begin{array}{c}\text { Chi- } \\
\text { square }\end{array}$ & Sig. \\
\hline Adaptive instruction & 64 & 94 & 30 & 5.69 & .01 \\
\hline $\begin{array}{l}\text { Student-directed } \\
\text { instruction }\end{array}$ & 91 & 105 & 14 & 1.00 & .31 \\
\hline Direct instruction & 130 & 153 & 23 & 1.86 & .17 \\
\hline $\begin{array}{l}\text { Promote students' } \\
\text { thinking }\end{array}$ & 71 & 89 & 18 & 2.02 & .15 \\
\hline $\begin{array}{l}\text { Academic performance } \\
\text { feedback }\end{array}$ & 93 & 118 & 25 & 2.96 & .08 \\
\hline Total & 449 & 559 & 110 & 12.00 & .00 \\
\hline
\end{tabular}


Regarding instructional strategies, the difference between the observed and expected frequencies for adaptive instruction, and academic performance feedback were statistically significant $(p<.05)$. It indicates that the teachers' self-efficacy beliefs were not realized with respect to them; however, as to student-directed instruction, direct instruction, promoting students' thinking, and academic performance feedback, there were no significant differences between the observed and expected frequencies. It implies that EFL teachers' self-efficacy beliefs were realized with respect to them and the strategies were implemented in teaching. Nonetheless, the total frequencies for the instructional strategies section of the observation form also showed a significant difference between the observed and expected frequencies, which means that on the whole, with regard to instructional strategies, the teachers' instructional practices could not reflect their self-efficacy beliefs. Table 15 presents similar results, except for the behavioral management strategies section of the observation form.

Table 15. Chi-square Results for Behavioral Management Strategies Section of the Observation Form

\begin{tabular}{|l|c|c|c|c|c|}
\hline $\begin{array}{c}\text { Behavioral } \\
\text { Management } \\
\text { Strategies }\end{array}$ & $\begin{array}{c}\text { Observed } \\
\text { Frequency }\end{array}$ & $\begin{array}{c}\text { Expected } \\
\text { Frequency }\end{array}$ & $\begin{array}{c}\text { Discrepancy } \\
\text { Score }\end{array}$ & $\begin{array}{c}\text { Chi- } \\
\text { square }\end{array}$ & Sig. \\
\hline $\begin{array}{l}\text { Proactive } \\
\text { Management }\end{array}$ & 104 & 115 & 11 & .55 & .45 \\
\hline $\begin{array}{l}\text { Behavior } \\
\text { Directives }\end{array}$ & 97 & 114 & 17 & 1.37 & .24 \\
\hline Behavior Praise & 52 & 71 & 19 & 2.93 & .08 \\
\hline $\begin{array}{l}\text { Behavior } \\
\text { Directive } \\
\text { Feedback }\end{array}$ & 61 & 71 & 10 & .75 & .38 \\
\hline Total & 314 & 317 & 57 & .01 & .90 \\
\hline
\end{tabular}

With respect to behavioral management strategies, the difference between the observed and expected frequencies for proactive management, behavior directives, behavior praise, and behavior directive feedback was not of statistical significance $(p>.05)$, indicating that the behavioral management strategies were implemented and accordingly the teachers' self-efficacy beliefs emerged as instructional practices in regard to them. Moreover, the total observed and expected frequencies for the behavioral management strategies section of the 
observation form showed no significant difference, and thus it implied the realization of the teachers' self-efficacy beliefs in their classroom practices.

\section{Discussion}

The primary goal of the present study was to probe the nature of EFL teachers' self-efficacy in the Iranian context. The overall TSEBs were found to be high. The surveyed EFL teachers regarded themselves as high-efficacious with respect to three subscales of self-efficacy beliefs wherein the teachers reported their ability in employing instructional strategies, student engagement techniques, and classroom management strategies. All the three subscales of teachers' self-efficacy evidenced means well above the average with student engagement yielded the highest overall mean score, followed by classroom management and instructional strategies. It suggests that in the present research, the teachers perceived their abilities to motivate and engage students to learn English higher than their capabilities in classroom management and instructional strategies. This result ties in with previous studies by Chacon (2005) and Eslami and Fatahi (2008) in which the EFL teachers rated themselves as highefficacious; however, in these studies, instructional strategies obtained the highest ratings, followed by classroom management and student engagement strategies respectively.

The fact that TSEBs were found to be relatively high implied a couple of reasons. Firstly, they might have had adequate knowledge and skills of effective teaching behaviors in terms of adopting proper instructional strategies, manage student behaviors well, and engage students sufficiently. Therefore, according to the finding of Washburn and Mulcay (2014) that teachers rate their teaching abilities based on their knowledge, the EFL teachers under investigation working in mentioned institutes with strict recruitment might justify the findings well. Additionally, by taking a closer look at teachers' sufficient teaching experience, this finding was expected because according to Bandura (1997), their mastery experience, that is, their previous successful experience, as one of the sources of self-efficacy, may explain the teachers' high self-efficacy scores.

Secondly, in contrast to the first assumption, teachers might overestimate their teaching abilities because they are unaware of their lack of knowledge. It echoes the Dunning-Kruger effect, wherein individuals of low ability mistakenly overrate themselves because of the unawareness of what they do not know (Kruger \& Dunning, 1999). A possible explanation for this result might be due to the possibility that survey responses may reflect cultural biases (King et al., 
2009), and thus the teachers report on what is desired and expected which may not be implemented in their daily flow of instruction. The trustworthiness of the obtained result will be examined in subsequent parts.

The second aim of the present study was to investigate the relationships between TSEBs and classroom practices. The results demonstrated a moderate positive relationship between TSEBs and communicative instructional practices. In other words, teachers with higher levels of self-efficacy tended to use communication-focused practices more frequently. The three subscales of selfefficacy were also significantly and positively correlated with communicative teaching. Put it another way, if teachers have stronger efficacy beliefs in employing instructional strategies, student engagement, and classroom management strategies, they will readily adopt communicative teaching. Employing instructional strategies was the most significant one, classroom management was the second-best predictor of the teachers' communicative practices, and finally, student engagement had the least contribution.

On the other hand, it was revealed that the correlation between TSEBs and non-communicative practices was a weak negative one, meaning that the higher the TESBs were, the less likely teachers were to use non-communicative teaching practices. Furthermore, none of the self-efficacy subscales were correlated with non-communicative teaching. Differently put, instructional strategies, student engagement, and classroom management strategies could not predict the non-communicative classroom practices of EFL teachers. Still, classroom management made the most contribution to explaining noncommunicative practices, followed by instructional strategies and student engagement.

Data from the interviews support quantitative analyses to some extent as the majority of interviewees reported using more communicative-oriented classroom practices but not to ignore the needed grammar instruction. Probably, the reason for adopting more explicit grammar instructional practices and translation, as an interviewee noted, lies in the attitudes based on some research such as De Fuente and Goldenberg (2020), indicating the necessity for using L1 to deepen the learning process as well as particular students' need. The finding from this part of the research was different from research by Chacón (2005), wherein there was a tendency towards the use of instructional practices consistent with the grammar-translation method partly as a matter of insufficient teachers' proficiency in speaking skill. 
The findings from the current study are in accordance with a recent study by Choi and Lee (2018) that the total score of self-efficacy was positively associated with communicative teaching; however, among the three subefficacies, only classroom management significantly predicted communicative teaching. It means that the less efficacious teachers felt about employing classroom management strategies, the more they tended to utilize noncommunicative teacher-fronted practices.

Finally, the present study is also in line with the finding of Eslami and Fatahi (2008) that the higher the teachers' sense of efficacy, the more tendencies they had to use communicative-based instructional practices in their classes. Moreover, there was an inclination to focus more on meaning rather than accuracy. In sum, self-efficacy beliefs could be a predictor to use more communicative- oriented instructional practices.

The third goal of the current research study was to examine the extent to which TSEBs were realized in instructional practices. It was revealed that the difference between the observed and expected frequencies for two subscales of instructional strategies (IS) section of the observation form, adaptive instruction and academic performance feedback, were statistically significant. It indicates that the teachers' self-efficacy beliefs towards such strategies were not realized concerning them; however, as to the other three subscales of student-directed instruction, direct instruction, and promoting students' thinking strategies, the discrepancy score was not significant. It suggests that although the EFL teachers under investigation kept up with their claims as to actively engage students in the learning process, deliver academic content, and activate students' thinking, they were not capable enough to adapt instructions. Thus, teachers lacked flexibility and responsiveness to students' needs. The probable explanation might lie in some syllabi imposed on teachers by institutes' managers or coaching consultants which made them not be able to adjust instruction. This finding surprisingly was contrary to the claim offered in interviews that students' needs would take priority. Additionally, teachers could not provide sufficient feedback to their students. The finding from this part of the research is partially in line with Poulou et al. (2019), in which one of the discrepancy scores was found for academic performance feedback to students' performance.

Regarding student engagement strategies, the corresponding subsection termed as student-directed teaching, as mentioned, showed no significant difference. In other words, teachers were capable of exploiting practices that encompass linking lesson content to prior learning and personal experiences. 
Nonetheless, the total frequencies for the instructional strategies showed a significant difference between the observed and expected frequencies, which means that on the whole, with regard to instructional strategies, the teachers could not utilize differentiated instruction and their efficacy beliefs did not emerge in classrooms. A similar result was obtained in the study by Poulou et al. (2019).

The result from the behavioral management strategies (BMS) section of the observation form showed no significant difference, and thus implied the realization of the TSEBs in their instructional practices. It suggests that teachers could prevent students' disruptive behaviors as well as create a positive classroom environment. Such a result could be justified in terms of the context of teaching; in other words, adult English learners registered in private language institutes tend to have enough motivation and determination for learning which results in positive classroom disciplinary climate, hence it was not needed to control students' behaviors. This finding is not consistent with Poulou et al. (2019) regarding behavioral management strategies wherein the teachers did not exhibit sufficient praise and behavior corrective feedback and what was expected; therefore, their perception did not seem to match their performance.

\section{CONCLUSIONS}

The primary finding revealed that teachers perceived high levels of efficacy to implement the necessary teaching strategies. Additionally, higher TSEBs led to more communicative-oriented practices; however, some high-efficacious teachers believed in employing more explicit instruction and using L1 to deepen the learning process. Moreover, the mismatch between CLT features and standardized testing prevented teachers to apply what they believe. Given that, such constraints and other sociocultural factors or probably the unrealistic views teachers have about their abilities resulted in the third finding of this investigation. Instructional strategies such as responsiveness to students' needs and necessary academic feedback did not emerge in classrooms. Still, teachers succeeded in implementing student engagement and classroom management strategies according to the observations conducted.

Studies like the present one, by depicting such inconsistency can raise the awareness of EFL teachers about their professed beliefs, as Feryok (2005) stated, "teachers need to become aware of what they do and do not know" (p.1). Furthermore, it paves the way for teacher trainers to modify coaching programs 
based on the issues wherein teachers report a lack of confidence. Developmental teacher training programs could encompass both increasing TSEBs by the most influential source of efficacy, that is, positive feedback on performance and designing training lessons to make teachers more efficient in practice. Additionally, the awareness of differing self-efficacy levels among teachers enables teacher trainers to offer an individual teacher the necessary help.

The CSAS observation form (Reddy et al., 2013) is ideally a multi-rater teacher classroom observation assessment; however, in the current research, the researcher, as the only observer, rated the strategies adopted in classrooms. This limitation precludes firm conclusions being drawn from the findings. Future studies are recommended to benefit from multiple numbers of observers. Likewise, at minimum a single observation can be used to complete the CSAS observation form; however, it is advised to use multiple observations and follow aggregation procedures. This research study was conducted with a limited number of volunteered participants; therefore, a wider scope involving more participants would raise the generalizability of the results.

Moreover, the current study was done on a group of EFL teachers instructing adult learners. Further studies can be done concerning young English learners who demand more efficacy regarding classroom management strategies on part of teachers. Future research can also be done to determine the various factors such as culture which may influence how teacher self-efficacy is developed and assessed on a qualitative investigation using case studies in the Iranian EFL context. Finally, personality traits such as self-criticism play a role in teachers' perceived efficacy and thus can be investigated in future studies.

\section{REFERENCES}

Bandura, A. (1977). Self-efficacy: Toward a unifying theory of behavioral change. Psychological Review, 84(2), 191-215. https://doi.org/10.1037/0033-295X.84.2.191

Bandura, A. (1986). Social foundations of thought and action: A social cognitive theory. Prentice-Hall.

Chacón, C. T. (2005). Teachers' perceived efficacy among English as a foreign language teachers in middle schools in Venezuela. Teaching and Teacher Education, 21(3), 257-272. https://doi.org/10.1016/j.tate.2005.01.001

Choi, E., \& Lee, J. (2018). EFL teachers' self-efficacy and teaching practices. ELT Journal, 72(2), 175-186. https://doi.org/10.1093/elt/ccx046 
Mirmojarabian \& Rezvani, Self-Efficacy Beliefs and Instructional Practices 291

Coladarci, T. (1992). Teachers' sense of efficacy and commitment to teaching. The Journal of Experimental Education, 60(4), 323-337. https://doi.org/10.1080/00220973.1992.9943869

De Fuente, M.J., \& Goldenberg, C. (2020). Understanding the role of the first language (L1) in instructed second language acquisition (ISLA): Effects of using a principled approach to L1 in the beginner foreign language classroom. Language Teaching Research, 18(3), 200-215. https://doi.org/10.1177/1362168820921882

Eslami, Z. R., \& Fatahi, A. (2008). Teachers' sense of self-efficacy, english proficiency, and instructional strategies: A study of nonnative EFL teachers in Iran. TESL-EJ, 11(4), 1-19. https://eric.ed.gov/?id=EJ898136

Feryok, A. (2005). Personal practical theories: Exploring the role of language teacher experiences and beliefs in the integration of theory and practice [Doctoral dissertation, University of Auckland, New Zealand]. ResearchSpace@Auckland

Fusch, P. I., \& Ness, L. R. Are we there yet? Data saturation in qualitative research. Qualitative Report, 20(9), 1408-1416. https://doi.org/10.46743/2160-3715/2015.2281

Ganjabi, M., Jafarigohar, M., Soleimani, H., \& Iravani, H. (2013). Investigating the role of self-efficacy in manipulating instructional textbooks: A matter of Iranian language teachers. International Journal of Applied Linguistics and English Literature, 2(6), 76-87. https://doi.org/10.7575/ aiac.ijalel.v.2n.6p.76

Hoang, T. (2018). Teacher self-efficacy research in English as foreign language contexts: A systematic review. The Journal of Asia TEFL, 15(4), 976-990. http://dx.doi.org/10.18823/asiatefl.2018.15.4.6.976

Holzberger, D., Philipp, A., \& Kunter, M. (2013). How teachers' self-efficacy is related to instructional quality: A longitudinal analysis. Journal of Educational Psychology, 105(3), 774-786. https://doi.org/10.1037/a0032198

Hoy, A. W., Hoy, W. K., \& Davis, H. A. (2009). Teachers' self-efficacy beliefs. In K. R. Wenzel \& A. Wigfield (Eds.), Handbook of motivation at school (pp. 627-653). Routledge.

Khosravi, M., \& Saidi, M. (2014). Investigating the possible relationship between multiple intelligences and self-efficacy: The case of Iranian EAP instructors. Electronic Journal of Foreign Language Teaching, 11(1), 90- 
97.

https://e-flt.nus.edu.sg/wpcontent/uploads/2020/09/v11n12014/khosravi.pdf

King, G., Murray, C. J., Salomon, J. A., \& Tandon, A. (2009). Enhancing the validity and cross-cultural comparability of measurement in survey research. Methoden der vergleichenden politik-und sozialwissenschaft [Methods of comparative politics and social science] (pp. 317-346). Springer. https://doi.org/10.1007/978-3-531-91826-6 16

Klassen, R. M., Tze, V. M., Betts, S. M., \& Gordon, K. A. (2011). Teacher efficacy research 1998-2009: Signs of progress or unfulfilled promise? Educationa Psychology Review, 23(1), 21-43. https://doi.org/10.1007/ s10648-010-9141-8

Kruger, J., \& Dunning, D. (1999). Unskilled and unaware of it: how difficulties in recognizing one's own incompetence lead to inflated self-assessments. Journal of Personality and Social Psychology, 77(6), 1121. https://doi.org/10.1037/0022-3514.77.6.1121

Lazarides, R., Buchholz, J., \& Rubach, C. (2018). Teacher enthusiasm and selfefficacy, student-perceived mastery goal orientation, and student motivation in mathematics classrooms. Teaching and Teacher Education, 69, 1-10. https://doi.org/10.1016/j.tate.2017.08.017

Moafian, F., \& Ghanizadeh, A. (2009). The relationship between Iranian EFL teachers' emotional intelligence and their self-efficacy in language institutes. System, 37(4), 708-718. https://doi.org/10.1016/j.system. 2009.09.014

Moe, A. (2016). Harmonious passion and its relationship with teacher wellbeing. Teaching and Teacher Education, 59, 431-437. https://doi.org/10.1016/j.tate.2016.07.017

Moradkhani, S., Raygan, A., \& Moein, M. S. (2017). Iranian EFL teachers' reflective practices and self-efficacy: Exploring possible relationships. System, 65, 1-14. https://doi.org/10.1016/j.system.2016.12.011

Morris, D. B., Usher, E. L., \& Chen, J. A. (2017). Reconceptualizing the sources of teaching self-efficacy: A critical review of emerging literature. Educational Psychology Review, 29(4), 795-833. https://doi.org/10.1007/ s10648-016-9378-y

Ortaçtepe, D., \& Akyel, A. S. (2015). The effects of a professional development program on English as a foreign language teachers' efficacy and classroom practice. TESOL Journal, 6(4), 680-706. https://doi.org/10.1002/tesj.185 
Phan, N. T. T., \& Locke, T. (2016). Vietnamese teachers' self-efficacy in teaching English as a foreign language. English Teaching: Practice \& Critique. 15(1), 105-128. http://doi.org/10.1108/ETPC-04-2015-0033

Poulou, M. S., Reddy, L. A., \& Dudek, C. M. (2019). Relation of teacher selfefficacy and classroom practices: A preliminary investigation. School Psychology International, $40(1), \quad 25-48$. https://doi.org/10.1177/0143034318798045

Rashidi, N., \& Moghadam, M. (2014). The effect of teachers' beliefs and sense of self-Efficacy on Iranian EFL learners' satisfaction and academic achievement. TESL-EJ, $18(2) . \quad \mathrm{http} / / \mathrm{www} . t e s 1-$ ej.org/wordpress/issues/volume18/ej70/ej70a3/

Reddy, L. A., Fabiano, G., Dudek, C. M., \& Hsu, L. (2013). Development and construct validity of the classroom strategies scale-observer form. School Psychology Quarterly, 28(4), 317-341. https://doi.org/10.1037/spq0000043

Richards, J. C. (2008). Second language teacher education today. Relc Journal, 39(2), 158-177. https://doi.org/10.1177/0033688208092182

Siwatu, K. O. (2011). Preservice teachers' sense of preparedness and selfefficacy to teach in America's urban and suburban schools: Does context matter? Teaching and Teacher Education, 27(2), 357-365. https://doi.org/10.1016/j.tate.2010.09.004

Swanson, P. (2014). The power of belief: Spanish teachers' sense of efficacy and student performance on the national Spanish examinations. Hispania, 97(1), 5-20. https://doi.org/10.1353/hpn.2014.0015

Thornbury, S. (2000). A dogma for EFL. IATEFL Issues, 153, 2. http://nebula.wsimg.com/5663ba0b760132a894433eb2c1faec95?AccessK eyId=186A535D1BA4FC995A73\&disposition=0\&alloworigin $=1$

Tschannen-Moran, M., \& Hoy, A. W. (2001). Teacher efficacy: Capturing an elusive construct. Teaching and Teacher Education, 17(7), 783-805. https://doi.org/10.1016/S0742-051X(01)00036-1

Tschannen-Moran, M., Hoy, A. W., \& Hoy, W. K. (1998). Teacher efficacy: Its meaning and measure. Review of Educational Research, 68(2), 202-248. https://doi.org/10.3102/00346543068002202

Washburn, E. K., \& Mulcahy, C. A. (2014). Expanding preservice teachers' knowledge of the English language: Recommendations for teacher educators. Reading \& Writing Quarterly, 30(4), 328-347. https://doi.org/10.1080/10573569.2013.819180 
294 TEFLIN Journal, Volume 32, Number 2, July 2021

Wertheim, C., \& Leyser, Y. (2002). Efficacy beliefs, background variables, and differentiated instruction of Israeli prospective teachers. The Journal of Educational Research, 96(1), 54-63. https://doi.org/10.1080/ 00220670209598791

Wyatt, M. (2018). Language Teachers' Self-efficacy Beliefs: A Review of the Literature (2005-2016). Australian Journal of Teacher Education, 43(4). http://dx.doi.org/10.14221/ajte.2018v43n4.6 